ISSN: 1858-4837; E-ISSN: 2598-019X

Volume 16, Nomor 2 (2021),

https://jurnal.uns.ac.id/region

DOI: 10.20961/region.v16i2.34272

\title{
Studi tingkat aksesibilitas sumber air penanggulangan kebakaran di Kecamatan Tambora Kota Administrasi Jakarta Barat
}

\author{
The Accessibility Level Study of Fire Fighting Water Sources in Tambora District \\ the Administrative City of Jakarta Barat
}

\author{
D N Tsaqila ${ }^{1}$, N Miladan ${ }^{1}$, dan R P Utomo ${ }^{1}$ \\ ${ }^{1}$ Program Studi Perencanaan Wilayah dan Kota, Fakultas Teknik, Universitas Sebelas \\ Maret
}

Corresponding author's email: difanurts21@gmail.com

\begin{abstract}
Abstrak. Kebakaran merupakan salah satu bencana yang sering melanda permukiman. Adanya kebakaran dapat memberikan kerugian terutama kerugian material. Kawasan permukiman yang sering dilanda kebakaran pada umumnya merupakan kawasan permukiman padat. Salah satu provinsi dengan kawasan permukiman padat yang cukup banyak yaitu Provinsi DKI Jakarta. Tercatat 1.471 kejadian kebakaran di DKI Jakarta pada tahun 2018. Kecamatan dengan angka kebakaran tertinggi di DKI Jakarta yakni Kecamatan Tambora. Pada tahun 2018, kejadian kebakaran di Kecamatan Tambora dapat mencapai 45 kejadian kebakaran. Penyebab utama kebakaran didominasi oleh masalah jaringan listrik. Penyebab utama kebakaran yakni masalah jaringan listrik dan kepadatan wilayah yang sangat tinggi. Kemudahan memperoleh prasarana kebakaran dan menuju titik kebakaran menjadi hal yang penting dalam proses pemadaman api. Penelitian ini bertujuan untuk mengetahui tingkat aksesibilitas prasarana kebakaran di permukiman padat Kecamatan Tambora, salah satunya tingkat aksesibilitas sumber air untuk penanggulangan kebakaran. Penelitian ini menggunakan pendekatan deduktif serta teknik analisis buffer, skoring, dan deskriptif. Data untuk melakukan analisis diperoleh dari kegiatan observasi lapangan, kuisioner dan wawancara, serta dokumen institusi. Hasil analisis menunjukkan bahwa $82 \%$ dari luas kawasan Kecamatan Tambora memiliki tingkat aksesibilitas terhadap sumber air penanggulangan kebakaran yang rendah, dan $18 \%$ lainnya dengan tingkat aksesibilitas terhadap sumber air penanggulangan kebakaran sedang. Tingkat aksesibilitas prasarana kebakaran tersebut dipengaruhi oleh terbatasnya ketersediaan
\end{abstract}


prasarana sumber air penanggulangan kebakaran berupa hidran dan adanya sisi sungai yang tidak dapat diakses oleh masyarakat setempat.

Kata Kunci: Aksesibilitas; Kecamatan Tambora; Sumber Air Penanggulangan Kebakaran

\begin{abstract}
Fires is one of disasters that frequently hit settlements. The fires result in losses, especially material loss. Residential areas that are often affected by fires are generally in the area of high population density. One of provinces with quite a lot of high population density areas is DKI Jakarta Province. There are 1.471 fires recorded in DKI Jakarta in 2018. Fires commonly happen in Tambora District, the administrative city of Jakarta Barat. In 2018, fires in Tambora District could reach 45 incidents. The main cause is dominated by electricity problems and high population density. The convenient access to the fire infrastructure and to the point of fire is important in the process of fire-fighting. The fire infrastructure that should have convenient access I is water sources. This study aims to determine the accessibility level of fire infrastructure in Tambora District. Accessibility analysis of fire infrastructure was carried out using overlay and scoring analysis techniques. Data analysis was obtained from field observations, questionnaires and interviews, as well as institutional documents. The analysis shows that $82 \%$ of the Tambora District area has a low accessibility of firefighting water sources, and $18 \%$ has a medium accessibility of fire-fighting water sources. The level of accessibility is influenced by the limited availability of fire hydrants as fire-fighting water source infrastructure and the river sides that cannot be accessed by the local community.
\end{abstract}

Keywords: Accessibility; Fire-fighting Water Sources; Tambora District

\title{
1. Pendahuluan
}

Kebakaran merupakan salah satu bencana yang sering terjadi di Indonesia. Kebakaran yang sering terjadi antara lain kebakaran hutan, kebakaran lahan, kebakaran di kawasan industri, dan kebakaran di permukiman. Kebakaran menjadi salah satu bencana yang sering melanda area permukiman, padahal permukiman merupakan kawasan yang bersinggungan langsung dengan kegiatan masyarakat. Adanya kebakaran tentu dapat mengganggu aktivitas masyarakat dan dapat memberikan kerugian terutama kerugian material. Sehingga, kebakaran memiliki keterkaitan dengan kerugian. Semakin meningkatnya kuantitas kebakaran, kerugian yang dialami masyarakat pun semakin besar.

Frekuensi kebakaran di sebagian provinsi di Indonesia berbeda-beda. Sebagian kota memiliki frekuensi kebakaran hanya beberapa kali dalam sebulan atau bahkan setahun, namun beberapa provinsi lainnya lebih sering mengalami kebakaran. Salah satunya yakni DKI Jakarta, kebakaran merupakan peristiwa yang cukup sering terjadi. DKI Jakarta menjadi provinsi yang paling banyak menyumbang kebakaran, terutama kebakaran permukiman. Tercatat 1.471 kejadian kebakaran yang melanda permukiman di DKI Jakarta pada tahun 2018 . Sebanyak $71 \%$ kebakaran tersebut disebabkan oleh adanya masalah pada jaringan listrik [1]. Area di Provinsi 
DKI Jakarta yang sering dilanda kebakaran yaitu Kota Administrasi Jakarta Barat dan Jakarta Utara. Area dengan kepadatan bangunan yang tinggi termasuk kedalam kawasan yang rawan terhadap kebakaran [1]. Area dengan kepadatan penduduk tertinggi di DKI Jakarta yakni Kecamatan Tambora, dimana area tersebut juga sering dilanda kebakaran [2].

Proses pemadaman api merupakan hal yang harus segera dilakukan apabila terjadi kebakaran. Proses pemadaman api dibantu oleh ketersediaan prasarana kebakaran. Ketersediaan prasarana kebakaran di Kecamatan Tambora yang terbatas memberikan dampak adanya kawasan yang tidak terjangkau oleh beberapa prasarana kebakaran. Selain itu permasalahan aksesibilitas petugas pemadaman dalam mencapai titik kebakaran dan memperoleh prasarana kebakaran menjadi hal yang penting. Namun kenyataannya, ketika proses pemadaman masih sering terjadi keterlambatan petugas sampai ke lokasi kejadian. Adanya permasalahan aksesibilitas akan mempengaruhi waktu dimulainya proses pemadaman api. Oleh karena itu, penelitian ini akan menganalisis tingkat aksesibilitas prasarana kebakaran.

\section{Metode}

Penelitian ini bertujuan untuk mengetahui tingkat aksesibilitas prasarana kebakaran di permukiman padat Kecamatan Tambora. Jenis penelitian ini merupakan penelitian kuantitatif dengan pendekatan penelitian deduktif. Penelitian kuantitatif menurut Nana Sudjana dan Ibrahim [3] merupakan jenis penelitian yang didasarkan pada asumsi untuk kemudian menetapkan variabel sebagai batasan dalam penelitian. Sedangkan pendekatan deduktif diawali dengan adanya eksplorasi teori terkait penelitian kemudian menghasilkan variabel dari sintesis teori tersebut. Variabel yang digunakan dalam penelitian ini yaitu ketersediaan prasarana kebakaran dan aksesibilitas.

Tabel 1. Variabel penelitian [4-8].

\begin{tabular}{|c|c|c|c|}
\hline Variabel & Sub-variabel & Definisi operasional & Indikator \\
\hline \multirow{2}{*}{$\begin{array}{l}\text { Ketersediaan prasarana } \\
\text { kebakaran }\end{array}$} & Hidran & Ketersediaan hidran & $\begin{array}{l}\text { Dalam } 1 \mathrm{~km} \text { minimal tersedia } 4-5 \\
\text { hidran }\end{array}$ \\
\hline & $\begin{array}{l}\text { Sumber air } \\
\text { tambahan }\end{array}$ & $\begin{array}{l}\text { Ketersediaan sumber air } \\
\text { tambahan }\end{array}$ & $\begin{array}{l}\text { Dalam kondisi baik (air mengalir, } \\
\text { debit air yang cukup) }\end{array}$ \\
\hline \multirow{3}{*}{ Aksesibilitas } & & Hidran & $\begin{array}{l}\text { Hidran memiliki jangkauan } \\
\text { pelayanan } 30-38 \mathrm{~m}\end{array}$ \\
\hline & Jarak & Sumber air tambahan & $\begin{array}{l}\text { Dapat menjangkau kawasan di } \\
\text { sekitarnya }\end{array}$ \\
\hline & Waktu & $\begin{array}{l}\text { Waktu yang dimaksud yakni } \\
\text { waktu tanggap }\end{array}$ & 5 menit (travel time) \\
\hline
\end{tabular}

Metode pengumpulan data dilakukan dengan survey data primer dan data sekunder. Pengumpulan data dengan survey data primer dilakukan melalui kegiatan wawancara dan observasi lapangan. Pengumpulan data primer dilakukan untuk megidentifikasi kondisi prasarana kebakaran dan komponen aksesibilitas. Sedangkan untuk pengumpulan data sekunder dilakukan dengan mengajukan permohonan permintaan data ke dinas terkait 
seperti Suku Dinas Pemadam Kebakaran Kota Administrasi Jakarta Barat. Selain itu data penggunaan lahan diperoleh melalui Google Earth tahun 2019.

Teknik analisis yang digunakan dalam penelitian ini yakni analisis spasial dan analisis skoring. Kerangka analisis dalam penelitian ini dapat dilihat pada Gambar 1.

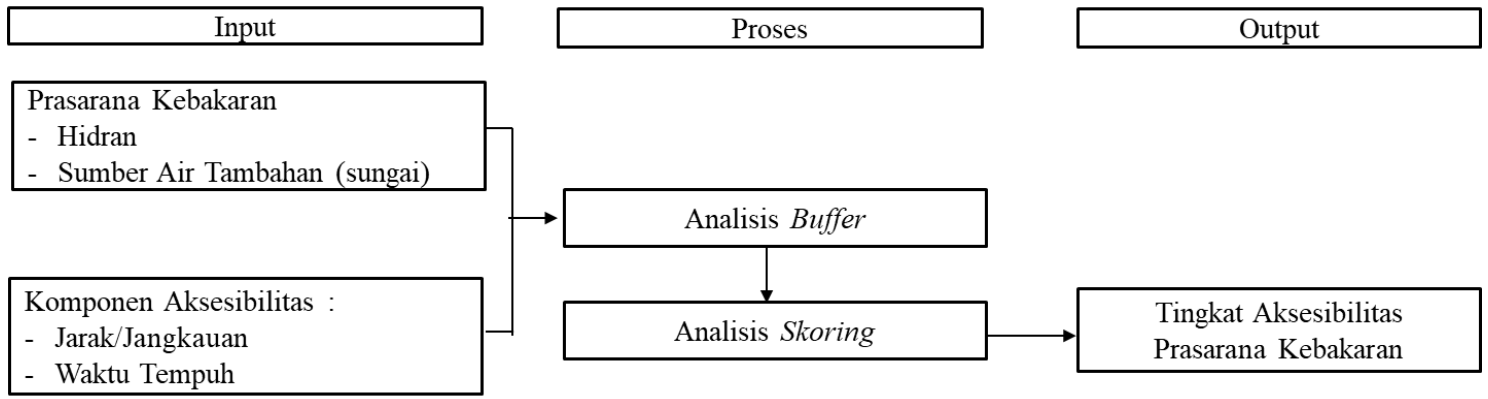

Gambar 1. Kerangka analisis penelitian.

Tabel 2. Skoring variabel prasarana kebakaran berdasarkan variabel aksesibilitas.

\begin{tabular}{|c|c|c|c|}
\hline Penilaian & $\begin{array}{l}\text { Prasarana } \\
\text { Kebakaran } \\
\end{array}$ & Kriteria & Skor \\
\hline \multirow{6}{*}{ Ketersediaan } & \multirow{3}{*}{ Hidran } & Ada dan sumber air mencukupi & 3 \\
\hline & & Ada, tetapi sumber air sedikit & 2 \\
\hline & & Ada dan tidak bisa digunakan/tidak ada sama sekali & 1 \\
\hline & \multirow{3}{*}{$\begin{array}{l}\text { Sumber air } \\
\text { tambahan }\end{array}$} & Ada dan sumber air mencukupi & 3 \\
\hline & & Ada, tetapi sumber air sedikit & 2 \\
\hline & & Ada dan tidak bisa digunakan/tidak ada sama sekali & 1 \\
\hline \multirow{6}{*}{$\begin{array}{l}\text { Jangkauan (sub- } \\
\text { variabel } \\
\text { aksesibilitas) }\end{array}$} & \multirow{3}{*}{ Hidran } & Mampu melayani $66,7 \%-100 \%$ lokasi peneitian & 3 \\
\hline & & Mampu 33,3\%-66,7\% lokasi peneitian & 2 \\
\hline & & Mampu melayani dibawah 33,3\% dari lokasi penelitian & 1 \\
\hline & \multirow{3}{*}{$\begin{array}{l}\text { Sumber air } \\
\text { tambahan }\end{array}$} & Mampu melayani 66,7\%-100\% lokasi peneitian & 3 \\
\hline & & Mampu 33,3\%-66,7\% lokasi peneitian & 2 \\
\hline & & Mampu melayani dibawah 33,3\% dari lokasi penelitian & 1 \\
\hline \multirow{3}{*}{$\begin{array}{l}\text { Waktu } \\
\text { (sub-variabel } \\
\text { aksesibilitas) }\end{array}$} & \multirow{3}{*}{$\begin{array}{l}\text { Pos Pemadam } \\
\text { Kebakaran }\end{array}$} & Kurang dari 5 menit & 3 \\
\hline & & 5 menit & 2 \\
\hline & & Lebih dari 5 menit & 1 \\
\hline
\end{tabular}

Menurut Keele dalam Soelistijadi \& Sunardi [9] analisis spasial memiliki karakter utama yaitu mampu melakukan analisis statistik dan analisis overlay. Analisis spasial yang digunakan yaitu analisis buffer. Analisis buffer merupakan teknik analisis yang berfungsi untuk mengidentifikasi hubungan antara objek pemetaan dengan lingkungan di sekitarnya. Analisis buffer menghasilkan zona pelayanan dalam jarak tertentu [10]. Pada umumnya analisis buffer digunakan untuk menganalisis area pelayanan sarana dan prasarana. Analisis buffer dapat menghasilkan suatu tingkatan pada skala tertentu yang menunjukkan pengaruh nilai terhadap area di sekitarnya [11]. Prasarana kebakaran pos pemadam akan dinilai berdasarkan jarak (jangkauan) dan waktu tempuh untuk memperoleh luas jangkauan pelayanan pos tersebut. Analisis buffer tersebut kemudian digunakan untuk menjadi batas dalam melakukan analisis skoring. Skor yang digunakan berdasarkan batas minimal dari masing-masing prasarana 
kebakaran dan aksesibilitas. Skoring mengenai prasarana kebakaran berdasarkan aksesibilitasnya dapat dilihat pada Tabel 2.Analisis skoring yang digunakan menggunakan 3 pilihan skoring, yaitu skor 1 untuk kategori aksesibilitas terhadap pos pemadam kebakaran rendah, skor 2 untuk kategori aksesibilitas terhadap pos pemadam kebakaran sedang, dan skor 3 untuk kategori aksesibilitas terhadap pos pemadam kebakaran tinggi dengan perhitungan interval sebagai berikut:

$$
\begin{aligned}
\text { Interval } & =(\text { nilai } \max -\text { nilai } \min ) / 3 \\
& =(18-6) / 3=4
\end{aligned}
$$

Berdasarkan perhitungan interval tersebut diperoleh kategori sebagai berikut:

- $\quad$ Kategori rendah memiliki nilai $=6-10$

- $\quad$ Kategori sedang memiliki nilai $=10.1-14$

- $\quad$ Kategori tinggi memiliki nilai $=14.1-20$

\section{Hasil penelitian dan pembahasan}

\subsection{Hasil analisis}

Analisis buffer digunakan sebagai analisis yang menunjukkan jangkauan pelayanan dari masing-masing prasarana kebakaran. Hasil analisis buffer tersebut kemudian diberi penilaian berdasarkan skor yang telah ditentukan. Skor yang berlaku pada penelitian ini yakni skor 1, 2, dan 3. Masing-masing besaran skor yang diberikan berdasarkan kriteria tiap prasarana. Proses analisis buffer pada sungai juga menggunakan bantuan tools fishnet untuk meningkatkan akurasi jarak jangkauan. Jumlah hidran di Kecamatan Tambora yakni 27 buah berdasarkan data dari open street map tahun 2017. Akan tetapi, setelah dilakukan survey lapangan, diketahui bahwa yang berfungsi hanya 4 buah hidran dan 1 hidran lainnya dalam kondisi rusak. Sehingga dalam analisis buffer, hidran yang di analisis hanya hidran yang masih berfungsi dengan baik. Hasil analisis jangkauan hidran dan sungai berdasarkan jarak di Kecamatan Tambora dapat dilihat pada Gambar 2.

Berdasarkan Gambar 2, hidran yang dapat digunakan mampu memenuhi kriteria jangkauan maksimalnya yakni $38 \mathrm{~m}$. Adanya keterbatasan jumlah hidran, sehingga tidak seluruh kawasan Kecamatan Tambora dapat dijangkau oleh hidran tersebut. Selain itu hidran dapat diakses dalam waktu tempuh yang singkat dan kurang dari 5 menit karena posisi hidran yang berada di tengah permukiman. Kemudian, untuk analisis jangkauan sumber air tambahan, tidak seluruh sisi sungai dapat dijangkau dari permukiman. Biasanya pemanfaatan air sungai sebagai prasarana kebakaran maksimal pada jarak 120 m, karena adanya keterbatasan pada panjang selang pemancar. Selain itu badan sungai yang tidak bisa digunakan dikarenakan beberapa sebab seperti posisi bangunan yang membelakangi sungai sehingga tidak ada ruang untuk peletakan pompa dan adanya pembatas antara permukiman dengan sungai berupa jalan, namun jalan tersebut memiliki tinggi yang berbeda dengan permukiman dan sungai sehingga untuk menjangkau sungai dari permukiman tidak memungkinkan. Tabel 3 merupakan tabel skoring setelah dilakukannya analisis jangkauan. 


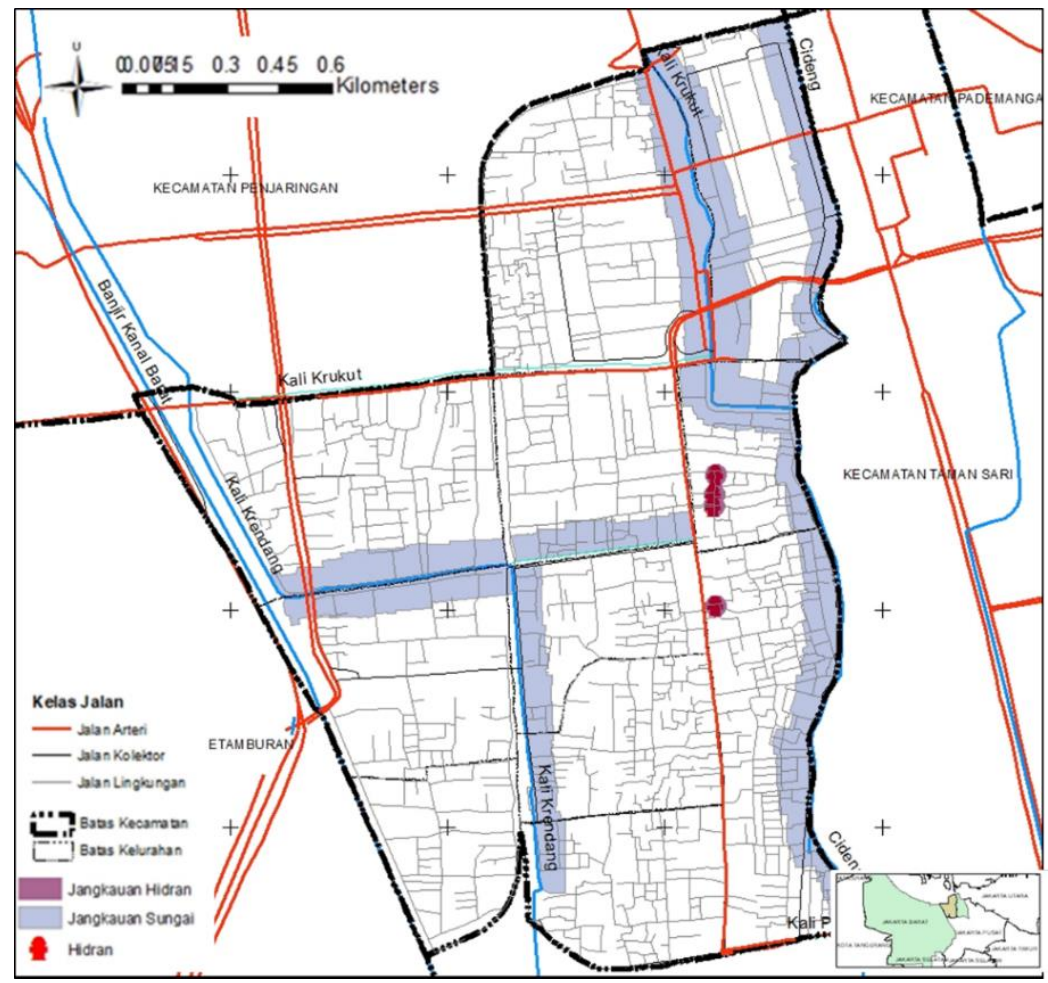

Gambar 2. Analisis jangkauan sumber air penanggulangan kebakaran di Kecamatan Tambora.

Pada Tabel 3 ditunjukkan adanya penilaian '0' untuk prasarana kebakaran hidran di beberapa kelurahan. Penilaian dilakukan karena tidak adanya hidran yang tersedia di kelurahan tersebut. Hasil analisis menunjukkan bahwa sumber air untuk penanggulangan di Kecamatan Tambora sebagian besar termasuk ke dalam kategori rendah. Dari 11 kelurahan hanya 2 kelurahan yang termasuk ke dalam kategori sedang.

Tabel 3. Skoring sumber air untuk penanggulangan kebakaran di Kecamatan Tambora.

\begin{tabular}{|c|c|c|c|c|c|c|}
\hline \multirow{2}{*}{ Kelurahan } & \multirow{2}{*}{ Prasarana Kebakaran } & \multirow{2}{*}{ Ketersediaan } & \multicolumn{2}{|c|}{ Aksesibilitas } & \multirow{2}{*}{ Skor } & \multirow{2}{*}{$\begin{array}{l}\text { Total } \\
\text { Skor }\end{array}$} \\
\hline & & & Jarak & Waktu & & \\
\hline \multirow{2}{*}{ Angke } & Hidran & 1 & 0 & 0 & 1 & \multirow{2}{*}{8} \\
\hline & Sumber Air Tambahan & 3 & 1 & 3 & 7 & \\
\hline \multirow{2}{*}{ Duri Selatan } & Hidran & 1 & 0 & 0 & 1 & \multirow{2}{*}{8} \\
\hline & Sumber Air Tambahan & 3 & 1 & 3 & 7 & \\
\hline \multirow{2}{*}{ Duri Utara } & Hidran & 1 & 0 & 0 & 1 & \multirow{2}{*}{8} \\
\hline & Sumber Air Tambahan & 3 & 1 & 3 & 7 & \\
\hline \multirow{2}{*}{ Jembatan Besi } & Hidran & 1 & 0 & 0 & 1 & \multirow{2}{*}{8} \\
\hline & Sumber Air Tambahan & 3 & 1 & 3 & 7 & \\
\hline \multirow{2}{*}{ Jembatan Lima } & Hidran & 2 & 0 & 0 & 2 & \multirow{2}{*}{9} \\
\hline & Sumber Air Tambahan & 3 & 1 & 3 & 7 & \\
\hline \multirow{2}{*}{ Kalianyar } & Hidran & 1 & 0 & 0 & 1 & \multirow{2}{*}{2} \\
\hline & Sumber Air Tambahan & 1 & 0 & 0 & 1 & \\
\hline \multirow{2}{*}{ Krendang } & Hidran & 1 & 0 & 0 & 1 & \multirow{2}{*}{8} \\
\hline & Sumber Air Tambahan & 3 & 1 & 3 & 7 & \\
\hline Roa Malaka & Hidran & 1 & 0 & 0 & 1 & 8 \\
\hline
\end{tabular}

Copyright $\odot$ 2021, REGION: Jurnal Pembangunan Wilayah dan Perencanaan Partisipatif 


\begin{tabular}{|c|c|c|c|c|c|c|}
\hline \multirow{2}{*}{ Kelurahan } & \multirow{2}{*}{ Prasarana Kebakaran } & \multirow{2}{*}{ Ketersediaan } & \multicolumn{2}{|c|}{ Aksesibilitas } & \multirow{2}{*}{ Skor } & \multirow{2}{*}{$\begin{array}{l}\text { Total } \\
\text { Skor }\end{array}$} \\
\hline & & & Jarak & Waktu & & \\
\hline & Sumber Air Tambahan & 3 & 1 & 3 & 7 & \\
\hline \multirow{2}{*}{ Tambora } & Hidran & 3 & 1 & 3 & 7 & \multirow{2}{*}{14} \\
\hline & Sumber Air Tambahan & 3 & 1 & 3 & 7 & \\
\hline \multirow{2}{*}{ Tanah Sereal } & Hidran & 2 & 1 & 3 & 6 & \multirow{2}{*}{13} \\
\hline & Sumber Air Tambahan & 3 & 1 & 3 & 7 & \\
\hline \multirow[b]{2}{*}{ Pekojan } & Hidran & 1 & 0 & 0 & 1 & \multirow[b]{2}{*}{8} \\
\hline & Sumber Air Tambahan & 3 & 1 & 3 & 7 & \\
\hline
\end{tabular}

\subsection{Keterbatasan sumber air untuk penanggulangan kebakaran di Kecamatan Tambora}

Penanggulangan kebakaran memerlukan air sebagai prasarana utama untuk membantu proses pemadaman api. Sumber air yang digunakan dapat diperoleh dari hidran dan sumber air tambahan lainnya seperti sungai ataupun sumur [12]. Jenis hidran yang dimaksud yakni hidran kota atau hidran lingkungan, dapat berbentuk hidran pilar ataupun hidran tanam. Mirsa dalam Arsana [13] mengemukakan pendapat bahwa seharusnya ketersedian hidran yang ideal dalam $1 \mathrm{~km}$ kurang lebih harus terdapat setidaknya 4-5 buah hidran.

Ketersediaan sumber air di Kecamatan Tambora cukup langka. Kelangkaan tersebut dinilai dari jumlah yang terbatas dan sedikitnya hidran yang berfungsi. Kecamatan Tambora idealnya, memiliki hidran lingkungan minimal 12 buah. Hidran yang ditemukan di Kecamatan Tambora merupakan hidran box, dimana 4 hidran box berfungsi dan 1 hidran box dalam kondisi rusak (lihat Gambar 3). Hidran yang berfungsi berada di Kelurahan Tambora dan Tanah Sereal, sedangkan yang tidak berfungsi berada di Kelurahan Duri Selatan. Persentase luas kawasan Kelurahan Tambora yang terlayani oleh hidran sebanyak 4,8\% dari luas Kelurahan Tambora. Hal ini dikarenakan hidran yang tersedia berjumlah lebih dari satu buah, sedangkan hidran di Kelurahan Tanah Sereal dapat melayani 0,72\% kawasan Kelurahan Tanah Sereal.

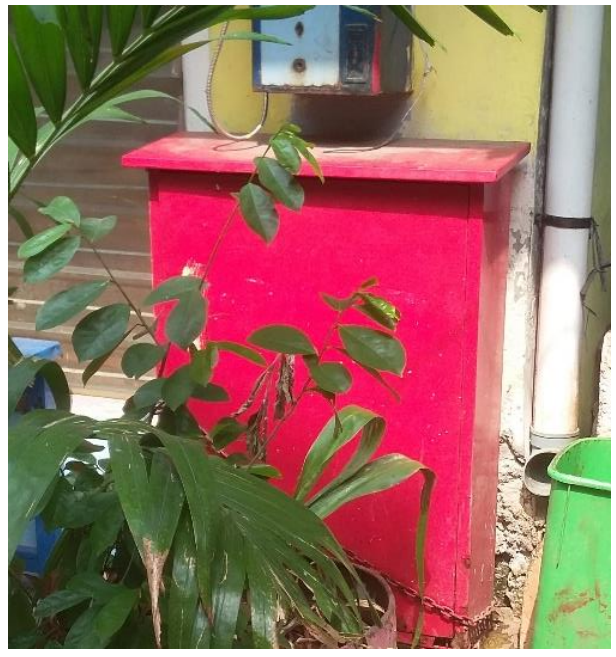

(1) Hidran yang masih berfungsi di Kecamatan Tambora

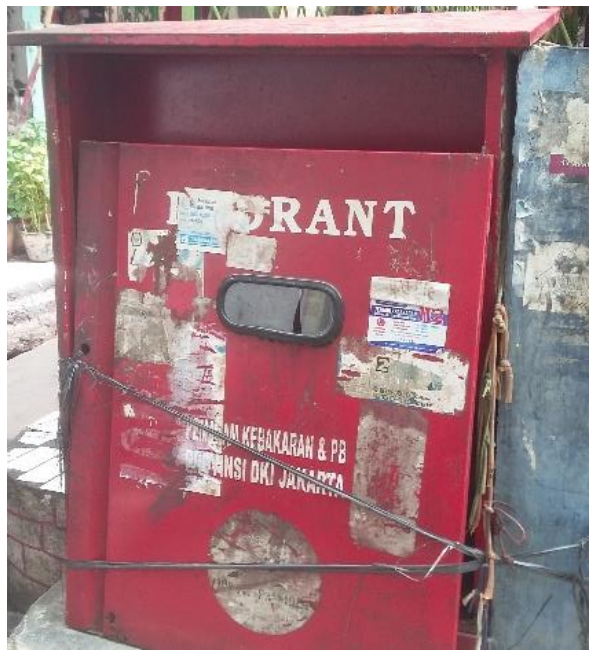

(2) Hidran yang sudah rusak di Kecamatan Tambora

Gambar 3. Kondisi hidran di Kecamatan Tambora. 
Jumlah hidran yang terbatas berdampak pada meningkatnya kinerja prasarana kebakaran yang lainnya seperti sumber air tambahan. Penggunaan sumber air tambahan pun belum tentu efektif karena masih harus melalui prosedur pemasangan pompa untuk melakukan distribusi air dari sungai. Langkanya hidran di Kecamatan Tambora mendorong masyarakat memanfaatkan sumber air lainnya seperti sungai. Keberadaan sungai di Kecamatan Tambora sangat mudah ditemui. Sungai yang melintas di Kecamatan Tambora berjumlah tiga yaitu Kali Krendang, Sungai Cideng, dan Kali Krukut. Debit air di tiap sungai dianggap cukup untuk pasokan air pada proses pemadaman api karena ketersediaan air selalu ada meskipun pada musim kemarau. Selain sungai, sumber air yang juga digunakan yakni air dari PDAM. Penggunaan air PDAM tersebut dikarenakan tidak adanya sumur atau tandon air di tengah permukiman, terutama permukiman padat.

Masyarakat setempat juga menjadikan air galon sebagai sumber air tambahan lainnya. Hal ini dipengaruhi oleh posisi lokasi kebakaran yang biasanya berada di tengah permukiman padat sehingga sulit dijangkau oleh petugas pemadam kebakaran. Distribusi air dari sumber tambahan tergolong sulit. Sungai menjadi alternatif tambahan air untuk pemadaman api, distribusi air dari sungai juga tidak selalu dapat digunakan. Beberapa faktor yang menjadi penyebab distribusi air sungai tidak dapat dilakukan yaitu posisi bangunan, adanya penghalang, dan perbedaan ketinggian sungai dengan permukiman. Ilustrasi mengenai penampang yang menggambarkan posisi sungai dengan permukiman dapat dilihat pada Gambar 4.

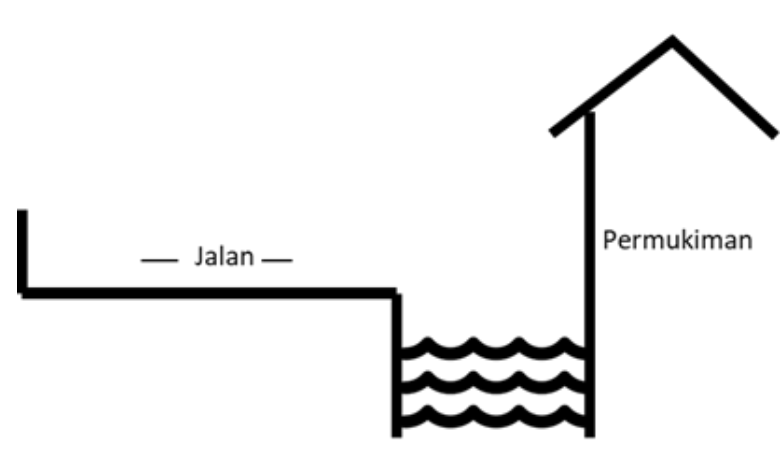

Gambar 4. Ilustrasi posisi bangunan dengan sungai.

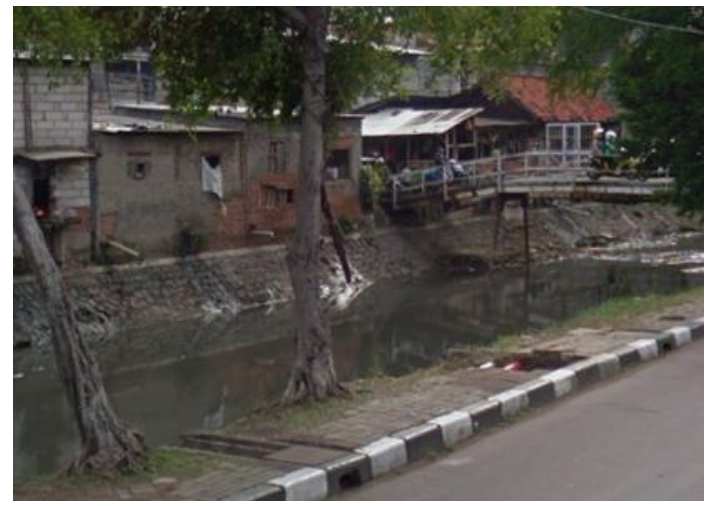

Gambar 5. Posisi bangunan dengan sungai.

Gambar 4 menjelaskan bahwa adanya bangunan yang berbatasan langsung dengan sungai dan tidak ada ruang untuk meletakkan pompa guna mendistribusikan air dari sungai. Apabila posisi bangunan menghadap ke sungai, akan lebih mudah karena di depan rumah umumnya terdapat jalan untuk mobilisasi masyarakat sehari-hari sehingga lebih memungkinkan untuk memanfaatkan air sungai sebagai sumber tambahan dalam pemadaman api. Akibat terbatasnya ketersediaan serta luas jangkauan kedua sumber air untuk penanggulangan kebakaran, berakibat pada rendahnya akses terhadap prasarana sumber air di sebagian besar 
kawasan Kecamatan Tambora. Sedangkan dokumentasi untuk ilustrasi posisi bangunan dengan sungai ditunjukkan oleh Gambar 5.

\section{Kesimpulan}

Tingkat aksesibilitas terhadap sumber air guna penanggulangan kebakaran di Kecamatan Tambora terbagi menjadi dua kategori yaitu rendah dan sedang. Kelurahan dengan tingkat aksesibilitas sumber air penanggulangan yang sedang berada di Kelurahan Tambora dan Tanah Sereal, sedangkan tingkat aksesibilitas yang rendah berada di 9 kelurahan lainnya. Kedua kelurahan dengan tingkat aksesibilitas sumber air penanggulangan yang sedang disebabkan karena adanya hidran yang masih berfungsi. Sedangkan kondisi 9 kelurahan lainnya tidak terdapat hidran ataupun hidran yang tersedia rusak. Selain itu adanya bagian sungai yang tidak dapat dimanfaatkan oleh masyarakat menjadi alasan lain dari rendahnya tingkat aksesibilitas sumber air penanggulangan.

\section{Ucapan Terima Kasih}

Penulis ingin mengucapkan terima kasih kepada Program Studi Perencanaan Wilayah dan Kota, Fakultas Teknik, Universitas Sebelas Maret yang telah memfasilitasi kegiatan penelitian tugas akhir dengan judul Tingkat Aksesibilitas Sumber Air Penanggulangan Kebakaran di Permukiman Padat Kecamatan Tambora Kota Administrasi Jakarta Barat. Penulis juga ingin menyampaikan terima kasih kepada instansi Kota Administrasi Jakarta Barat yang telah memberikan data yang diperlukan oleh penulis terkait penelitian ini.

\section{Referensi}

[1] Dinas Penyelamatan dan Penanggulangan Kebakaran. Portal Data Terpadu Pemprov DKI Jakarta. 2018.

[2] Dinas Kependudukan dan Pencatatan Sipil DKI Jakarta. Portal Data Terpadu Pemprov DKI Jakarta. 2013.

[3] Sudjana N, Ibrahim. Penelitian dan Penilaian Pendidikan. Bandung: Sinar Baru Algensindo; 2001.

[4] Wilayah KP dan P. Keputusan Menteri Permukiman dan Prasarana Wilayah No. 534 Tahun 2001 tentang Pedoman Standar Pelayanan Minimal Pedoman Penentuan Standar Pelayanan Minimal Bidang Penataan Ruang, Perumahan Dan Permukiman Dan Pekerjaan Umum. 2001.

[5] Mirsa R. Elemen Tata Ruang Kota. Yogyakarta: Graha Ilmu; 2012.

[6] NFPA. National Fire Protection Association. n.d.

[7] Kementerian Pekerjaan Umum. Peraturan Menteri Pekerjaan Umum No. 20 Tahun 2009 tentang Pedoman Teknis Manajemen Proteksi Kebakaran di Perkotaan 2009.

[8] Badan Standarisasi Nasional. SNI 03-1735-2000: Tata Cara Perencanaan Akses Bangunan dan Akses Lingkungan Untuk Pencegahan Bahaya Kebakaran Pada Bangunan Gedung. 2000.

[9] Sunardi, N. DHU, Soelistijadi R. Pemanfaatan Analisis Spasial untuk Pengolahan Data Spasial Sistem Informasi Geografi. J Teknol Inf Din 2005;10:108-16.

[10] Prahasta E. Sistem Informasi Geografis Tutorial ArcView. Bandung: Informatika; 2002. 
[11] DeMers MN. GIS For Dummies. Indianapolis: Wiley Publishing Inc; 2009.

[12] Kementerian Negara Pekerjaan Umum. Keputusan Menteri Negara Pekerjaan Umum No.11 Tahun 2000 tentang Ketentuan Teknis Manajemen Penanggulangan Kebakaran di Perkotaan. 2000.

[13] Arsana IP. Perencanaan Prasarana Perkotaan. Yogyakarta: DeePublish; 2018. 